Commentary

Invited Commentary

Central Eur J Paed 2019;15(1):65-67

DOI $10.5457 / \mathrm{p} 2005-114.233$

\title{
Invited Commentary on "Dietary Sources of Vitamin D, Vitamin D Supplementation, and Its Bioavailability," by Kucan et al.: Vitamin D: An Ancient Enabler with a Modern Twist
}

\author{
Carol L. Wagner \\ Department of Pediatrics, Shawn Jenkins Children's \\ Hospital, Medical University of South Carolina, \\ Charleston, SC 29425 \\ Correspondence: \\ wagnercl@musc.edu \\ Tel.: + (001) 843-792-2112 \\ Fax.: + (001) 843-792-8801
}

Received: 27 December 2018

Accepted: 28 December 2018

Key Words: Vitamin D - Cholecalciferol • Supplementation.

In the past two decades there has been a tremendous increase in the number of studies conducted to determine what is truth surrounding vitamin D's role in the body-its effects not only on calcium and bone metabolism, but also on the immune system, as an enabler of the actions of other hormones, growth factors and cytokines within that broad system. There also have been a plethora of observational and randomized controlled trials to determine how much is really enough during the various times in the lifecycle, with specific attention to women during pregnancy (1-4) and lactation (5) and in the prevention of certain chronic diseases such as cardiovascular disease (6), cancers (7-9) and autoimmune diseases such as multiple sclerosis (10-12) and systemic lupus erythematosus
(13). There are conflicting data on any topic, showing benefit or not, and sometimes showing harm at concentrations above a certain level, especially when dosed with periodically high boluses (14). The interval between doses-daily, weekly, biweekly, monthly, quarterly or yearly can impact vitamin D metabolism significantly (15). As is pointed out in this review by Kucan et al. (16), there is little agreement on what constitutes sufficiency, how to measure the metabolite $25(\mathrm{OH}) \mathrm{D}$ in the blood, and even in the way vitamin D should be dosed.

Kucan et al. (16), rightfully identify the dietary sources of vitamin $\mathrm{D}$ and emphasize the need for vitamin $\mathrm{D}$ supplementation due to our lifestyle changes in the latter part of the 20th century and the invention of sunscreen, that for all intents and purposes, variably blocks vitamin $\mathrm{D}$ synthesis by the epidermis depending on how it is applied to the skin. What sets this review apart from others is the emphasis on how bioavailability of vitamin $\mathrm{D}$ can be affected by the other foods ingested. As is stated, for absorption to occur, vitamin $\mathrm{D}$ requires release from the very matrix that binds it-the food itself-affected by $\mathrm{pH}$, fat content and structural complexity (carbohydrates, protein), and the digestive enzymes themselves. Other vitamins (A, E and phytosterols, for example) can also affect vitamin $\mathrm{D}$ absorption from the gut. What is 
not mentioned that also can affect circulating $25(\mathrm{OH}) \mathrm{D}$ concentration and processing by cells is the vitamin $\mathrm{D}$ binding protein (VDBP), which depending on VDBP genotype, can affect the release of vitamin $\mathrm{D}$ and its metabolites to then act on the target cells/ systems in question (17).

In this review by Kucan et al. (16), the authors present us with useful, thoughtful information about a vitamin/preprohormone that while an ancient hormone, has much left to be discovered (18). What is clear based on this and other reviews is that because vitamin $\mathrm{D}$ is an enabler, one should not be vitamin $\mathrm{D}$ deficient, however one defines this. More studies that examine the interplay between genetic receptor variations (VDBP, vitamin $\mathrm{D}$ receptor itself) will help determine what sufficiency is in the context of one's genotype and epigenome. Until then, appreciating that "one-size-fits-all" might not be the best approach in prescribing vitamin $\mathrm{D}$ supplementation dosing, with measurement of $25(\mathrm{OH})$ $\mathrm{D}$ concentrations serving as the guide to achieving what would be attained through judicious sunlight exposure, the better option.

Disclosure: Dr. Wagner serves as a scientific consultant for Church \& Dwight, Princeton, NJ, USA and was an invited speaker at the Mead Johnson Pediatric Scientific Institute seminar on September 27, 2018.

\section{References}

1. Hollis BW, Johnson D, Hulsey TC, Ebeling M, Wagner CL. Vitamin D supplementation during pregnancy: double-blind, randomized clinical trial of safety and effectiveness. Journal of bone and mineral research : the official journal of the American Society for Bone and Mineral Research. 2011;26(10):2341-57.

2. Wagner CL, McNeil R, Hamilton SA, Winkler J, Rodriguez Cook C, Warner G, et al. A randomized trial of vitamin D supplementation in 2 community health center networks in South Carolina. Am J Obstet Gynecol. 2013;208(2):137 e1- e13.

3. Sablok A, Batra A, Thariani K, Batra A, Bharti R, Aggarwal AR, et al. Supplementation of vitamin D in pregnancy and its correlation with feto-maternal outcome. Clinical endocrinology. 2015;83(4):53641.

4. Roth DE, Morris SK, Zlotkin S, Gernand AD, Ahmed T, Shanta SS, et al. Vitamin D Supplementation in Pregnancy and Lactation and Infant Growth. The New England journal of medicine. 2018;379(6):535-46.

5. Hollis BW, Wagner CL, Howard CR, Ebeling M, Shary JR, Smith PG, et al. Maternal Versus Infant Vitamin D Supplementation During Lactation: A Randomized Controlled Trial. Pediatrics. 2015;136(4):625-34.

6. Jiang WL, Gu HB, Zhang YF, Xia QQ, Qi J, Chen JC. Vitamin D Supplementation in the Treatment of Chronic Heart Failure: A Meta-analysis of Randomized Controlled Trials. Clin Cardiol. 2016;39(1):56-61. doi: 10.1002/clc.22473. PubMed PMID: 26415519.

7. Mohr SB, Gorham ED, Kim J, Hofflich H, Garland CF. Meta-analysis of vitamin D sufficiency for improving survival of patients with breast cancer. Anticancer research. 2014;34(3):1163-6. PubMed PMID: 24596354.

8. Garland C, Comstock G, Garland F, Helsing K, Shaw E, Gorham E. Serum 25(OH)D and colon cancer: Eight-year prospective study. Lancet. 1989;2:1176-8.

9. Lee JE, Li H, Chan AT, Hollis BW, Lee IM, Stampfer MJ, Wu K, Giovannucci E, et al. Circulating levels of vitamin D and colon and rectal cancer: the Physicians' Health Study and a meta-analysis of prospective studies. Cancer prevention research. 2011;4(5):735-43. Epub 2011/03/25. doi: 19406207.CAPR-10-0289 [pii] 10.1158/1940-6207. CAPR-10-0289. PubMed PMID: 21430073.

10. Soilu-Hanninen M, Aivo J, Lindstrom BM, Elovaara I, Sumelahti ML, Farkkila M, et al. A randomised, double blind, placebo controlled trial with vitamin D3 as an add on treatment to interferon beta- $1 \mathrm{~b}$ in patients with multiple sclerosis. Journal of neurology, neurosurgery, and psychiatry. 2012. Epub 2012/03/01. doi: 10.1136/jnnp2011-301876. PubMed PMID: 22362918.

11. Kampman MT, Steffensen LH, Mellgren SI, Jorgensen L. Effect of vitamin D3 supplementation on relapses, disease progression and measures of function in persons with multiple sclerosis: exploratory outcomes from a double-blind randomised controlled trial. Multiple sclerosis. 2012. Epub 
2012/02/23. doi: 10.1177/1352458511434607. PubMed PMID: 22354743.

12. Dorr J, Ohlraun S, Skarabis H, Paul F. Efficacy of Vitamin D Supplementation in Multiple Sclerosis (EVIDIMS Trial): study protocol for a randomized controlled trial. Trials. 2012;13(1):15. Epub 2012/02/10. doi: 10.1186/1745-6215-13-15. PubMed PMID: 22316314.

13. Abou-Raya A, Abou-Raya S, Helmii M. The effect of vitamin D supplementation on inflammatory and hemostatic markers and disease activity in patients with systemic lupus erythematosus: a randomized placebo-controlled trial. The Journal of rheumatology. 2013;40(3):265-72. Epub 2012/12/04. doi: 10.3899/jrheum.111594. PubMed PMID: 23204220.

14. Sanders KM, Stuart AL, Williamson EJ, Simpson JA, Kotowicz MA, Young D, et al. Annual highdose oral vitamin $\mathrm{D}$ and falls and fractures in older women: a randomized controlled trial. JAMA: the journal of the American Medical Association. 2010;303(18):1815-22. Epub 2010/05/13. doi: 10.1001/jama.2010.594. PubMed PMID: 20460620 .
15. Hollis B, Wagner C. The Role of the Parent Com pound Vitamin D with Respect to Metabolism and Function: Why Clinical Dose Intervals Can Affect Clinical Outcomes. The Journal of Clinical Endocrinology \& Metabolism. 2013;98(12):461928. doi:10.1210/jc.2013-2653. PubMed PMID: 24106283.

16. Kucan R, Soltirovska S, Andronikov D, Benedik E. Dietary sources of vitamin $\mathrm{D}$, vitamin $\mathrm{D}$ supplementation, and its bioavailability. Central Eur J Paed. 2018;14(2):115-122.

17. Braithwaite VS, Jones KS, Schoenmakers I, Silver M, Prentice A, Hennig BJ. Vitamin D binding protein genotype is associated with plasma 25OHD concentration in West African children. Bone. 2015;74:166-70. Epub 2015/02/06. doi: 10.1016/j.bone.2014.12.068. PubMed PMID: 25652210 ; PMCID: PMC4366041.

18. Wagner CL, Eidelman AI. The Impact of Vitamin $\mathrm{D}$ on the Maternal and Infant Epigenome: The Role of Pregnancy and Breastfeeding. Breastfeed Med. 2018;13(5):305-6. Epub 2018/05/31. doi: 10.1089/bfm.2018.29093.clw. PubMed PMID: 29847150 . 